\title{
Fluid flow through nanopore space: discussion and proposition of a model for Polish shales
}

\begin{abstract}
Two main models of fluids flow through nanopore space were considered. Single tube capillary model (and its improvements) and net model of nanopore space. Flexibility, efficiency and reliability of each was taken into account. Among others the Javadpour model seems to be relatively reliable and easy to apply for Polish shale gas reservoirs. Additionally it is possible to improved it, by introducing results of new investigations, such as Klinkenberg permeability obtained by Pulse Decay measurements.
\end{abstract}

Key words: total flux, apparent permeability, nanopore space flow of fluids.

\section{Przepływ płynów przez nanoprzestrzeń porową: dyskusja i propozycja modelu adekwatnego do warunków polskich}

\begin{abstract}
Dwa główne typy modeli zostały poddane dyskusji. Model pojedynczej walcowej kapilary oraz model sieciowy bazujący na krzywej adsorpcji. Rozważano możliwości, elastyczność i rzetelność obu modeli. Model prezentowany przez Javadpoura, zmodyfikowany o wyniki badań efektu Klinkenberga przy zastosowaniu aparatu Pusle Decay wydaje się być najbardziej odpowiednim do szacowania przepuszczalności polskich złóż łupkowych.
\end{abstract}

Słowa kluczowe: całkowita wielkość przepływu, przepuszczalność pozorna, przestrzeń nanporowa, przepływ płynów.

\section{Introduction}

Permeability of shale gas reservoirs is still poorly understood. Recent high resolution imaging studies have shown that in shale reservoirs, matrix pores consist of pores from the size of micrometer down to the range of $2 \div 100 \mathrm{~nm}$ and pore throats may be as small as $0.5 \mathrm{~nm}[1,6,11,16,23]$.

Therefore, assumption of permeability for gas in shale gas reservoirs is a complex multiscale problem. So far, a lots of researches on transport mechanisms in shales (matrix and fractures) have been done [1-3, 7-22, 23-25, 28].

Modeling gas flow through nanoporous media must satisfy two factors: mathematic reliability of the model and its simplicity to use in practice. Additional restriction depends on accessibility of appropriate set of data. In nanopore space, flow regimes change in a function of pore distribution, pressure and temperature: from Darcy flow to molecular diffusion $[9,14,18]$ and thus flow model must cover the whole range of pores and reservoir conditions.

There are several models created mainly for American shale plays. However they cannot be directly applied to Polish shale gas formations because of shale heterogeneity and different mineral composition which affect pore size distribution and as a result flow properties.

This paper provides a quick review of different approaches to assume permeability of shale gas reservoirs and draws the attention to all the aspects which need to be considered before applying those models to Polish shale gas conditions.

\section{Flow regimes}

Generally simply, empirical Darcy's flow can be applicated to the range of pores from tens to hundreds of microns [13].
However, when the average mean free path of the gas molecules begins to be comparable to or greater than the pore 
size containing it, the continuum theory is not valid anymore. Knudsen number $(K n)$ which is defined as mean free path of gas molecule divided by mean diameter, describes different gas transport patterns in porous media. Following that classification below continuous flow zone, flow mechanism change and is called slip flow. Its lower critical pore radiuses strongly depends on pore pressure - when the pressure is less than $10 \mathrm{MPa}$, critical pore radiuses sharply increases as pressure decreases and when the pressure is greater than $10 \mathrm{MPa}$, critical pore diameter decreases slightly with the increase of pressure. The gas flow in that regime is influenced by both Darcy and slippage effect. The next zone is called the transition zone, in which mean free path and average diameter are in the same order of magnitude and as a result, the influence of collisions between gas molecules are as important as collisions of gas molecules and pore walls. The gas transport in this regime is a combination of slippage flow and Knudsen diffusion flow [3, 21]. Its boarders also depends on pressure $[28,29]$. The last regime is called the free molecular diffusion zone, where the gas transport only meets Knudsen diffusion.

In Polish shale differential pressures are from the range $2 \div 5 \mathrm{MPa}$. It means that the borders of zone must be established on the values: free molecular zone below $1 \mathrm{~nm}$, transition zone in the range $1 \div 40 \mathrm{~nm}$, and slip flow zone above

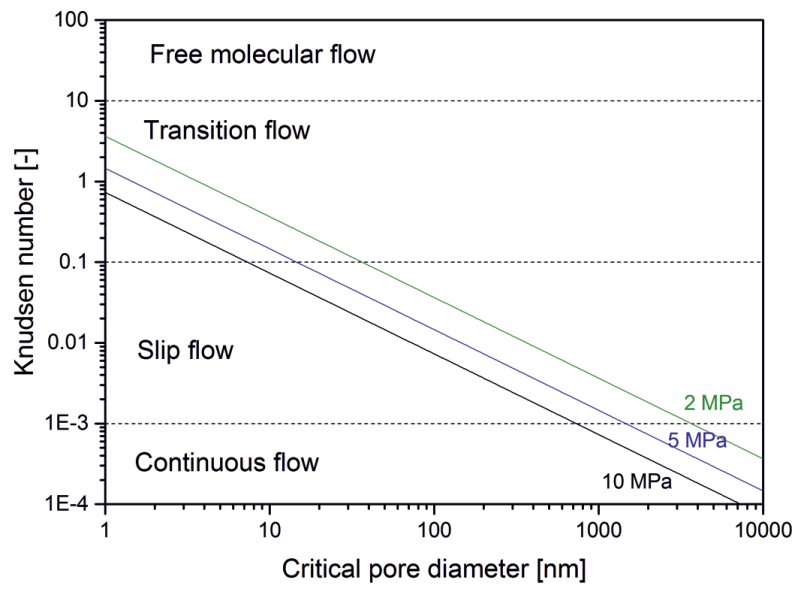

Fig. 1. Knudsen number as a function of critical pore diameter at $70^{\circ} \mathrm{C}$ [5 modified]

the range $15 \mathrm{~nm}-3 \mu \mathrm{m}$. Schematically described zones are presented in Fig. 1.

In conventional reservoirs Darcy permeability is widely used to compute gas flow. In the case of fine grained shale rocks, which contain micropores (noncontinuum effects) and nanopores (dominant surface interactive forces), Darcy equation cannot be used. In order to capture pore scale flow mechanisms in shale reservoirs in almost all studies, Darcy equation is modified by incorporating the physics at molecular level to account for higher equivalent permeability.

\section{Flow models review}

Models of flow in shales can be divided into two groups:

- single tube capillary and its improvements,

- net model.

The first started from Hagen-Pouiseuille equations which are modified for various flow mechanism. There are well known Javadpour works $[9,11]$ in which he considered slip flow and the Knudsen diffusion. The other interesting papers are Civan and Civan et al. [14, 15] who correlated the Klinkenberg effect and Brodi [3] who adopted various methods of pore radius evaluation in the scale of well. Clarkson et al. $[9,10]$ adopted adsorption processes. Many other scientists applied such types of flow models [4, 20, 24, 28]. All these parametrizations have two weak points. The first is that there are formulated for single nanotube and the second is parameter $\alpha$ in the final formula for permeability.

Typical workflow looks as follow:

Darcy permeability form Hagen-Pouiseuille law is expressed as:

$$
Q=\frac{\rho_{a v g} r^{2} \Delta p}{8 \mu L}
$$

where:

$Q$ - mass flux $\left[\mathrm{kg} / \mathrm{s} / \mathrm{m}^{2}\right]$,

$P$ - pressure $[\mathrm{Pa}]$,

$L$ - pore length [m],

$R$ - pore radius $[\mathrm{m}]$,

$\rho_{\text {avg }}-$ density $\left[\mathrm{kg} / \mathrm{m}^{3}\right]$,

$\mu-\operatorname{viscosity}[\mathrm{Pa} \cdot \mathrm{s}]$.

Taking into account gas slippage coefficient and gas diffusion so called apparent permeability is equal to:

$$
k_{\text {app }}=\frac{2 r \mu M}{3 \cdot 10^{3} R T \rho_{\text {avg }}^{2}} \sqrt{\frac{8 R T}{\pi M}}+F \frac{r^{2}}{8 \rho_{\text {avg }}}
$$

where:

$\mu$ - viscosity $[\mathrm{mPa} \cdot \mathrm{s}]$,

$R$ - gas constant $[\mathrm{J} / \mathrm{mol} / \mathrm{K}]$,

$T$ - temperature $[\mathrm{K}]$,

$M-$ molar mass $[\mathrm{kg} / \mathrm{kmol}]$.

In this formula factor $F$ (eq. 3) appears, introduced by Brown et al. [4], which is responsible for slip correction in tube and $F$ is a function of pore radius and $\alpha$. 


$$
F=1+\sqrt{\frac{8 \pi R T}{M}} \cdot \frac{\mu}{p_{\text {avg }} r}\left(\frac{2}{\alpha}-1\right)
$$

where:

$\alpha$-tangential momentum accommodation coefficient, fraction.

Finally, we have two unknown parameters: $r$ and $\alpha$ or $F$.

Javadpour et al. [14] and Bodi [3] used high pressure mercury injection capillary pressure (MICP) and apply most frequent or average radius of pores. The next step is calculation of $\mathrm{F}$ on the basis of obtained pore radius and estimated tangential momentum accommodation coefficient, which depends on pressure, temperature, gas type and morphology of pores [29] and may have the value from the range $0 \div 1$. In most of the works it was assumed on the level of $0.5 \div 0.8$.

Another expression of apparent gas permeability based on Hagen-Poiseuille type formulation, represents formulas verified by molecular dynamic (MD) models $[2,17]$ which are capable of modeling interaction of individual gas molecule at the pore wall and can be generally expressed by the formula:

$$
k=k_{\infty} f\left(K_{n}\right)
$$

where $f(K n)$ is a flow condition function given as a function of Knudsen number and $k_{\infty}$ is an intrinsic permeability.

Beskok and Karniadakis [2] developed a unified model that predicts the mass flow in channels and pipes cover all flow regimes.

$$
Q=-\frac{\pi r^{4}}{8 \mu} \frac{d P}{d x}(1+\alpha K n) \cdot\left(1+\frac{4}{1-b K n}\right)
$$

where:

$b$ - slip coefficient, dimensionless;

$\alpha$ - dimensionless rarefaction coefficient.

Based on this model Florence et al [12] proposed the following equation for apparent permeability:

$$
k_{a p p}=k_{\infty} \cdot(1+\alpha(K n) K n) \cdot\left(1+\frac{4 K n}{1+K n}\right)
$$

where the rarefaction coefficient is given by:

$$
\alpha(K n)=\frac{128}{15 \pi^{2}} \tan ^{-1}\left(4 K n^{0.4}\right)
$$

Based on the same model Civan [7] proposed a different solution for rarefaction coefficient:

$$
\alpha(K n)=\alpha_{0}\left(\frac{K n^{B}}{A+K n^{B}}\right)
$$

where empirically estimated values for tight gas sand were set as $\alpha_{0}=1.358, A=0,178, B=0,4348$ and $b=-1$ and so apparent permeability can be expressed by the following equation:

$$
K_{a p p}=k_{\infty}\left[1+1.358\left(\frac{K n^{0.4348}}{0.178+K n^{0.4348}}\right) K n\right] \cdot\left[1+\frac{4 K n}{1+K n}\right]
$$

Summary, of these methods give relatively simple models in which standard petroleum engineering parameters are used. Of course, one must very carefully examine the consistency of a model and control frames of its applicability. Molecular dynamic models are valid for every $K n$ but they are computationally inefficient and therefore of limited use for estimating permeability of large units such as shale plays [18].

An alternative approach in modeling is application of pore space net model with the use of fractal approach [4]. Net model requires estimation the number of pores in a function of their radiuses, estimated connectivity factor as well as tortuosity. Sheng [22] worked out a model on the basis of adsorption experimental pore radius distribution curves. The workflow is theoretically simple and contain the following steps:

- Existence of fractal structure of pore space allows to estimate number of pores [26]

$$
N(d)=\left(\frac{d_{i+1}}{d}\right)^{D}
$$

where:

$d$ - pore diameter,

$D$ - fractal dimension,

$N$ - number of pores $(d)$.

- Calculation of fractal diameter

$$
D=3-\frac{\ln (\text { por })}{\ln \left(d_{\min } / d_{\max }\right)}
$$

where:

$D$ - fractal dimension, por - total porosity.

- Estimation of total permeability (calculated for surface $A$ )

$$
K_{A}=\sum_{i=1}^{N} K_{A}^{i}
$$

where:

$i$ - part of permeability form Darcy type equation:

$$
K_{A}^{i}=\frac{\mu L Q_{i}}{\Delta p A_{i}}
$$

where:

$p$ - pressure difference,

$Q$ - volumetric flux, viscosity, 
$L$ - length of capillary pathway,

$A$ - cross sectional area.

- Estimation of permeability in the zone of Knudsen number between $0.1 \div 10$ using following formula:

$$
K_{A}^{i}=D \cdot d_{i+1}^{D} \cdot g(d)
$$

where $g(d)$ is equal to:

$$
g(d)=\int_{d_{i}}^{d_{i+1}} d^{-D-1} \frac{\pi d^{4}}{128}\left(1+\frac{\alpha \lambda}{d}\right) *\left(1+\frac{4 \lambda}{\lambda+d}\right) d(d)
$$

and additionally

$$
\alpha=\alpha_{0}\left(1+\frac{0.1780 d^{0.4348}}{\lambda^{0.4348}}\right)
$$

where:

$\lambda-$ is free mean path of molecules,

$\alpha_{0}-$ is $\alpha$ for Knudsen number reaching infinity.
The obtained formula has no analytical solution and GaussLegandre procedure must be used for calculation. Although, several approximations were applied, calculations are very complicated. Furthermore, some of the applied approximations are rather questionable (like transition from a discrete set of data to continuous function). Additionally, space heterogeneity is completely not taken into consideration.

Another disadvantage of this approach is its validity only in transition and free molecular zone and other formulas must be used in slip flow zone.

An alternative attempt at application of pore network model to determine permeability of shale gas matrix was done by Mehmani et al. [17]. Proposed 3D network model combines pores with nanometer and micrometer sizes with different flow physics mechanisms on both scales.

The most questionable assumption in this approach was applying a 3D connectivity factor similar to that of wellstudied sedimentary rocks.

\section{Discussion}

A group of flow models connected with Hagen-Pouiseille equation and a capillary tube are relatively simple and take into account Darcy flow, slip flow and the Knudsen equation. Additionally, several detailed updates were introduced into this model such as estimation of gas adsorption/desorption effect on permeability as well as some dynamic effects. Some works devoted to dusty flow model seems very inconvenient for application in oil and gas engineering practice.

The biggest advantage of this group of models is the possibility of verification of calculations with the use of experimental permeability results. In turn the base simplification and weakness of these models is taking into calculation single pore radius. Moreover, the Darcy equation assumes water wet conditions which may lead to underestimation of transport properties in shale rocks $[1,11]$.

The goal/aim of a/the fractal model is preparing a net model of nanopore space with all attributes of such model like distribution of pore radiuses, tortuosity etc. Nonetheless, practical introduction of these parameters is completely disappointing. Analysis of fractal dimension of pore radius distribution curves in transition zone showed that the assumption of single fractal dimension in the whole zone is not true [5]. Then $N$ (number of pores) zero measure set, suddenly became a continuous function and tortuosity is equal to zero. Finally, obtained formulas have no analytical solutions.

The real big problem of nanopore space is its heterogeneity. The thin section of shale rock samples presented in Fig. 2 raises the question, is there any net of pores (big or small) and are they connected. Such type of pore space is in fact closer to single tube model than to a regular net of pore bodies and channels.

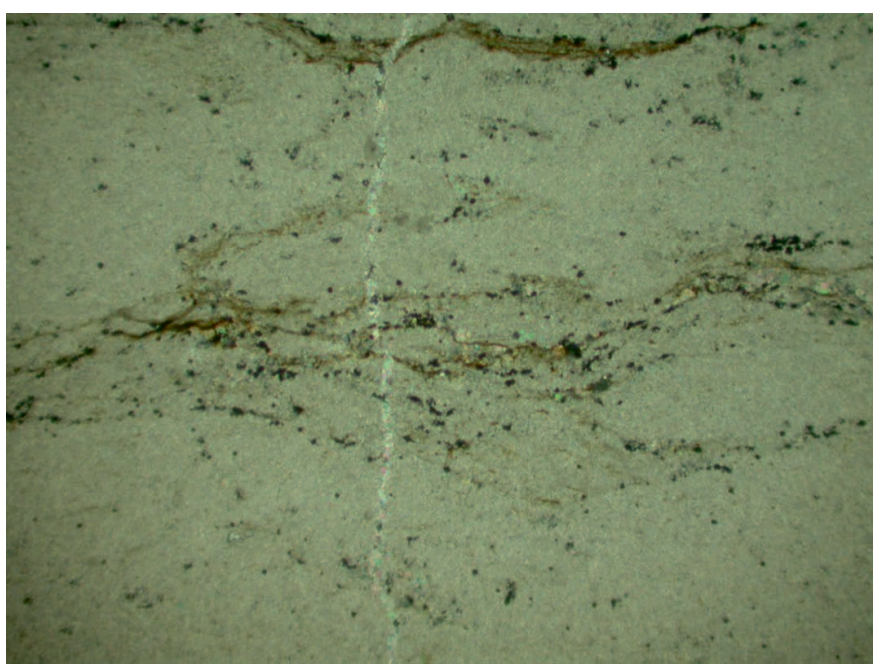

Fig. 2. Pore space of shale rock

Results presented in previous papers $[6,27,28]$ obtained with the use of mercury and helium density pycnometry, MICP, absorption TRISTAR device and Pulse Decay permeameter showed great heterogeneity and absence of fractal structure for the whole range $50 \div 2 \mathrm{~nm}$. Although, the set of measurements presented in the above mentioned papers allow us to estimate total and total open porosity, apparent permeability (in reservoir conditions) and pore size distribution in the whole interested pore scale, a general model of permeability is needed in order to upscale the above mentioned petrophysical properties to grid size block domains. 
Polish shale gas reservoirs are characterized by pore pressure from the range $2 \div 5 \mathrm{MPa}$ and temperature about $70^{\circ} \mathrm{C}$ $[25,26]$. It means that the transition zone covers the range of pore radius from 1 to $40 \mathrm{~nm}$. Above the transition zone is the slip flow zone. Our investigation shows that pore space of Polish shale could be divided into two parts. In Fig. 3 typical cumulative curves for both types are presented.

For the first group (type I) more than $70 \%$ of pore space is located in the transition zone. For those samples it will be necessary to discuss slip flow and Knudsen diffusion. Moreover, factor $F$ needs to be estimated with the use of experimental permeability analyses.

For the second ones (type II) a great part of pore volume is located in the slip flow zone. After estimating the impact of diffusion effects, it will be possible to apply standard calculation for the slip zone with experimentally calculated Klinkenberg coefficient.

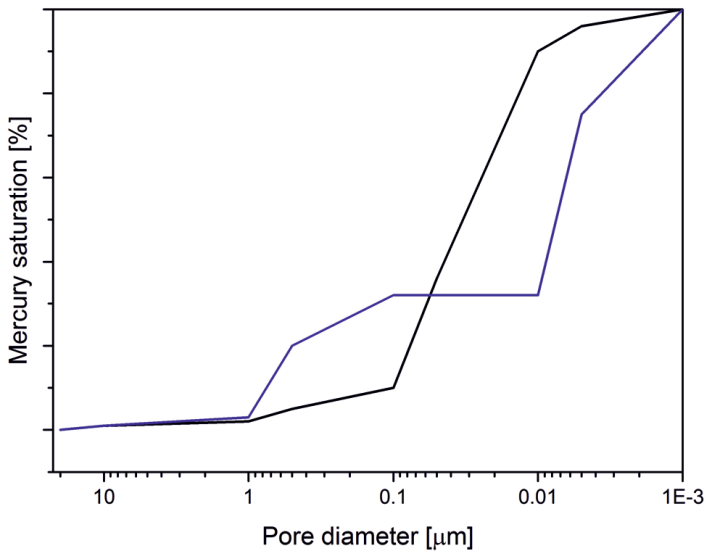

Fig. 3. Two types of pore space (blue line - type I, black line - type II) [25]

This kind of heterogeneity makes the knowledge of petrophysical parameters crucial to refine the model and to adjust it to Polish shales.

\section{Conclusion}

1. Flowing mechanism changes in a function of pore radiuses. This fact implicates applying various models of pore space:

- when pores greater than $100 \mathrm{~nm}$ are dominant classical Klinkenberg model and net model of pore space could be applied. A necessary condition is the same fractal dimension in the whole range of analyzed pore radiuses.

- for pore radiuses lower than $100 \mathrm{~nm}$ it is impossible to apply a net model because of various fractal dimension or absence of fractal structure in pore space.
Only the Javadpour or a modified Javadpour model could be applied.

2. Heterogeneity of Polish shale rocks, lack of regular net of pores and one fractal dimension in the whole range of pore space, as well as difficulties in estimating connectivity factor, make application of a net model to estimate permeability of Polish shales impossible.

3. Taking into consideration equations $(1) \div(3)$ and permeability measurements with the use of Pulse Decay apparatus it is possible to calculate all needed parameters for flow description.

Please cite as: Nafta-Gaz 2016, no. 10, pp. 779-784, DOI: 10.18668/NG.2016.10.01

Article contributed to the Editor 21.04.2016. Approved for publication 16.07.2016.

The article is the result of research conducted in connection with the project: The methodology for determining sweet spots on the basis of geochemical, petrophysical, geomechanical properties based on the correlation of laboratory test results with geophysical measurements and 3D generating model, co-funded by the National Centre for Research and Development as part of the programme BLUE GAS - POLISH SHALE GAS. Contract No. BG1/MWSSSG/13.

\section{Literature}

[1] Akkutlu Y., Fathi E.: Multiscale Gas Transport in Shales With Local Kerogen Heterogeneities. SPE Journal 2012, SPE 146422.

[2] Beskok A., Karniadakis G. E.: A model for flows in channels, pipes and ducts at micro and nano scales. Microscale Thermophy. Eng., 1999, vol. 3, pp. 3-77.

[3] Bodi T.: Gas flow in the nano size pore channels of tight and non conventional gas storage formation. Geosciences and Engineering 2012, vol. 1, no. 1, pp. 49-63.

[4] Brown G. P., Dinardo A., Cheng G. K., Sherwood T. K.: The Flow of Gases in Pipes at Low Pressures. Journal of Applied Phys. 1946, vol. 17, pp. 802-813.

[5] Cicha-Szot R., Dudek L., Such P.: Charakterystyka fraktalna przestrzeni porowej skat łupkowych. Przemysł Chemiczny 2015, vol. 94/12, pp. 1000-1007.

[6] Cicha-Szot R., Dudek L., Such P.: Permeability estimation in shale gas formations on the basis of desorption data and radial gas flow. Nafta-Gaz 2015, no. 11, pp. 833-839.

[7] Civan F.: Effective correlation of apparent gas permeability in tight porous media. Transport in porous media 2010, vol. 82 , pp. 375-384.

[8] Civan F., Rai C. S, Sondergeld C. H.: Shale-gas permeability and diffusivity inferred by improved formulation of relevant retention and transport mechanisms. Transport in porous media 2011, vol. 86, pp. 925-944. 
[9] Clarkson C. R., Nobakht M., Kaviani N., Ertekin T.: Production Analysis of Tight-Gas and Shale-Gas Reservoirs Using the Dynamic-Slippage Concept. SPE Journal 2012, vol. 17, pp. 230-242.

[10] Clarkson C. R., Solano N., Bustin R. M., Chalmers G. R. L., He L., Melnichenko Y. B., Radliński A. P., Blach T. P.: Pore structure characterization of North American shale gas reservoirs using USANS/SANS, gas adsorption, and mercury intrusion. Fuel 2013, vol. 103, pp. 606-616.

[11] Fathi E., Tinni A., Akkutlu Y.: Shale Gas Correction to Klinkenberg Slip Theory. SPE 154977, 2012.

[12] Florence F. A., Newsham J. A. R. K. E., Blasingame T. A.: Improved permeability prediction relations for low permeability sands. SPE 107954. Paper presented at SPE Rocky Mountain Oil \& Gas Technology Symposium: Flow in Porous Media Denver, Colorado, Texas: Society of Petroleum Engineers, 16-18 April 2007.

[13] Heller R., Vermylen J., Zoback M.: Experimental investigation of matrix permeability of gas shales. AAPG Bull. 2014, vol. 98, no. 5, pp. 975-995.

[14] Javadpour F.: Nanopores and Apparent Permeability of Gas Flow in Mudrocks (Shales and Siltstones). JCPT 2009, vol. 48, no. 8, pp. 16-21.

[15] Javadpour F., Fisher D., Unsworth M.: Nanoscale gas flow in shale gas sediments. Journal of Canadian Petroleum Technology 2007, vol. 46, no. 10, pp. 55-61.

[16] Leśniak G., Such P., Komorowska K.: Inaccessible porosity - insight to pore development and solutions to MICP data interpretation. Paper prepared for presentation at the International Symposium of the Society of Core Analysts held in Snow Mass, Colorado, 21-26 August 2016.

[17] Mehmani A., Prodanović M., Javadpour F.: Multiscale, Multiphysics Network Modeling of Shale Matrix Gas Flows. Transport of Porous Media 2013, vol. 99, pp. 377-390.

[18] Rezaee R.: Fundamentals of Gas Shale Reservoirs. Wiley 2015, ISBN 978-1-118-64579-6.

[19] Sakhaee-Pour A., Bryant S.: Gas permeability of shale. SPE Reservoir Evaluation \& Engineering 2012, vol. 15, pp. 401-409.

[20] Shabro V., Torres Verdin C., Javadpour F.: Numerical simulation of Shale gas Production: from Pore Scale modeling of Slip Flow, Knudsen Diffusion, and Langmuir Desorption to reservoir Modeling of Compressible Fluid. SPE 144355, 2011.

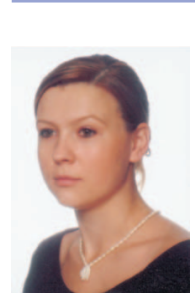

Renata CICHA-SZOT M.Sc. Eng.

Junior Scientist

Department of Petroleum Engineering

Oil and Gas Institute - National Research Institute

ul. Lubicz 25 A

31-503 Kraków

E-mail: renata.cicha@inig.pl
[21] Shabro V., Torres-Verdin C., Sepehmoori K.: Forecasting gas production in Organic Shale with the Combined Numerical Simulation of Gas Diffusion in Kerogen, Langmuir desorption from Kerogen Surfaces and Advection in nanopores. SPE 159250, 2012.

[22] Sheng M.: Shale gas permeability model with effect of multiscale flow based on fractal pore space geometry. Fractals 2015, D-14-00092.

[23] Solano N. A., Clarkson C. R., Krause F., Aquino S., Wiseman A.: On the Characterization of Unconventional Oil Reservoirs. CSEG Recorder 2013, pp. 42-47.

[24] Subrata R., Reni R., Chuang H. F., Cruden B. A., Meyyappan M.: Modeling gas flow through microchannels and nanopores. Journal of Applied Physics 2003, vol. 93, no. 8, pp. $4870-4879$.

[25] Such P.: Przepływ gazu przez nanopory - próba oceny. Nafta-Gaz 2014, no. 10, pp. 671-675.

[26] Such P.: Zastosowanie rachunku fraktalowego w badaniach przestrzeni porowej skat zbiornikowych. Prace Instytutu Górnictwa Naftowego i Gazownictwa 2002, nr 115.

[27] Such P. Dudek L., Mroczkowska-Szerszeń M., Cicha-Szot R.: Wplyw warunków złożowych na parametry filtracyjne skat tupkowych. Nafta-Gaz 2015, no. 11, pp. 816-827.

[28] Such P., Dudek L., Mroczkowska-Szerszeń M., Cicha-Szot R. The influence of reservoir conditions on filtration parameters of shale rocks. Nafta-Gaz 2015, no. 11, pp. 827-833.

[29] Wang R., Zhang N., Liu X., Wu X., Yan J.: Characterization of Gas Flow Ability and Contribution of Diffusion to Total Mass Flux in the Shale, Res. Journal of Applied Sciences, Engineering and Technology 2013, vol. 6, no. 9, pp. 1663-1668.

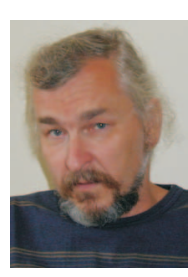

Prof. dr hab. Piotr Such

Assoc. Professor

Deputy Director

Exploration of Hydrocarbons

Oil and Gas Institute - National Research Institute

ul. Lubicz 25 A, 31-503 Kraków

E-mail:piotr.such@inig.pl

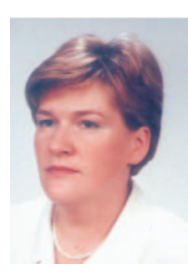

Lidia DUDEK M.Sc. Eng.

Senior Technical Research Specialist

Department of Geology and Geochemistry

Oil and Gas Institute - National Research Institute

ul. Lubicz 25 A

31-503 Kraków

E-mail:dudekl@inig.pl 